\title{
Studies on Germination Behaviour of Respective Seed Sources of Azadirachta indica
}

\author{
Sharda Dubey* and Gaurav Kumar Padwar \\ Department of Forestry, Faculty of Natural Resources, Guru Ghasidas Vishwavidyalaya, \\ Bilaspur, Chhattisgarh, India \\ *Corresponding author
}

\section{Ke y w o r d s \\ Azadirachtaindica, Germination Percentage, Germination value, Mean germination time, Seedlings vigour index, Moisture content, Seed weight \\ Article Info \\ Accepted: \\ 22 July 2020 Available Online: 10 August 2020}

\section{A B S T R A C T}

Azadirachta indica commonly known as neem belong to the family of Meliaceae. It is a valuable medicinal tropical tree species with many uses. Germination of neem seed is in the initial circumstance critical step in afforestation programmes or naturally conditions, Neem seed having short viability it's a kind of recalcitrant seeds so that is the problem in introducing neem to new locations. Fresh seeds germinate very soon, but within week's germination rates begin dropping off because seeds have low moisture content. This poses logistical difficulties for any tree-planting or improvement. Experiment was carried out at Nursery of Guru Ghasidas Central University Bilaspur Chhattisgarh, Germination percentage of among seed sources was recorded in Naryanpura gave maximum germination percentage $(94.33 \%)$, where seed soaked with water, while minimum value of germination percentage was recorded from Dhamatari $(85.89 \%)$. Where in the control there was no treatment recorded germination percentage in Bilaspur $(91.00 \%)$, while the minimum value of germination percentage was recorded from Dhamatari $(83.00 \%)$. Seed sources of Bilaspur gave maximum Seedling vigor index (SVI) (3744.27) while minimum Seedling vigor index (SVI)was recorded from Bijapur (2885.74), Where in the control there was no treatment recorded highest Seedling vigor index (SVI) Bilaspur (3854.76), while minimum Seedling vigor index (SVI) was recorded from Pendra (2979.07), Seed sources of Bilaspur gave maximum Drupe weight (169.36g ), where lowest Drupe weight was recorded Balod (142.34g), Seed sources of Bilaspur gave maximum Drupe weight without pulp (60.46g ), where lowest Drupe weight without pulp was recorded Balod (52.41g), Seed sources of Bilaspur gave maximum Moisture content (16.91\%), where lowest Moisture content was recorded Bemetera (13.51\%) was recorded Significant variations $(\mathrm{CD}=0.05)$.

\section{Introduction}

Azadirachta indica commonly known as neem belong to the family of Meliaceae. It is a valuable medicinal tropical tree species with many uses. Germination of neem seed is in the initial circumstance critical step in afforestation programmes or naturally conditions seed quality at the physiological level includes seed viability. Neem seed 
having short viability it's a kind of recalcitrant seeds so that is the problem in introducing neem to new locations. Fresh seeds germinate very soon, but within weeks germination rates begin dropping off because seeds have low moisture content. This poses logistical difficulties for any tree-planting or improvement. The viability of seed is simply its capacity for growth and development (Bewley \& Black, 1978). Germination capacity is a measure of the ability of a population of seeds to germinate, or as Bewley \& Black (1978) described it, "the maximum percentage of seeds that when germinating under favourable condition." Seeds of many tree species germinate readily when subjected to favourable conditions of moisture and temperature. But most of the species exhibit delayed germination due to some degree of seed dormancy. Rapid, uniform, early and complete germination are the pre-requisites for raising seedlings on large scale for any plantation programme. Seeds of most tree species are with a soft outer cover, the embryo of such seeds can be awakened rapidly when exposed to the warm moist environment and there is no need of any pre-treatment of these seeds before sowing (FAO, 1985). Seed germination has other utility also. Speed of germination has long been used as an indicator of vigour (AOSA, 1976). Seed vigour is an important factor determining seed quality in forest trees (Vlase and Voinesou, 1972). Seed vigour is one of the most important parameters in determining seed quality and it is the sum total of those properties of seed which determine the potential level of performance and activity of a non-dormant seed of a seed lot during germination and seedling emergence. Germination is the resumption of growth by the embryo plant which has lain dormant in the seed. This being as soon as the resting seed begins to imbibe moisture. Germination in the commonly accepted botanical use of the term occurs when the radical begins to protrude beyond the seed coat (Toumey and Stevens, 1982) of all the quality measurements on seeds, none is more important than how well they will germinate. This information is the deciding factor on the value of the seedlot. The seed must be exposed to favourable environmental conditions before germinating. The favourable environmental conditions are an adequate supply of water, and adequate gas exchange, and suitable temperature and light. Temperature is one of the most important environmental factors affecting seed germination. It affects the germination percentage as well as the rate of germination and varies with different species.

\section{Materials and Methods}

\section{Study area}

The study of the germination behaviour of respective seed sources of Azadirachta indica was carried out from different seed sources of ten districts of Chhattisgarh India, and germination of the seed is performed in the nursery of Guru Ghasidas Central University Bilaspur Chhattisgarh, situated in $22.12^{\circ}$ North and $82.13^{\circ}$ East soil type of the site is sandy to loam. The average temperature of the area is $29.5^{\circ} \mathrm{C}$, annual rainfall is about 58 $\mathrm{cm}$,

Experiments were carried out using mature fresh seeds from yellow fruits (Neem seeds called as Drupe)which was collected during June to August 2020, which were collected from plantations at the district of Chhattisgarh, namely, Balod, Bilaspur, Bemetara, Bijapur, Dhamtari, Gariaband, Pendra, Kondagaon, Mahasamund, Narayanpur. Seeds were planted on the nursery raise bed having a proper mixture of soil: sand: organic manure at $2-5 \mathrm{~cm}$ (plant to plant) $x 15-10 \mathrm{~cm}$ (row to row) spacing at 2.0$2.5 \mathrm{~cm}$ depth with three replication. Seed 
germination was recorded daily to a minimum of 28 days or until there was no further germination. The weeding, cleaning and watering of raise bed were done manually when needed. The raised bed were arranged RBD design with three replication.

\section{Seed pre-sowing treatment}

The experiment was carried out in the nursery of Department of Forestry, Faculty of Natural Resources, Guru Ghasidas Vishwavidyalaya, Bilaspur, Chhattisgarh. The sample of three hundred seeds per seed sources (three replications of 100 seeds of each treatment) was taken for study. Onraise bed with two pre-sowing treatments was employed, as mentation below:

$\mathrm{T}_{1}=$ Seeds without any treatment (control) $\mathrm{T}_{2}=$ Seeds soaked in normal water for 12 hours

After each pre-treatment, the seeds were sown in a raised bed for germination test in the nursery and the following parameters were recorded as given below:

\section{Germination percent (GP)}

Germination percent has recorded the percent of the sown seeds germinated at the completion of the test period, i.e., 28 days after sowing (ISTA, 1999). It was calculated by the following formula:

Total number of seed germinated

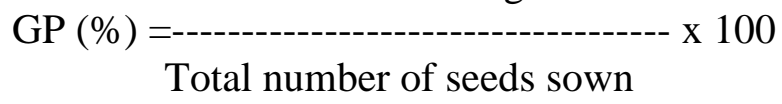

\section{Germination value (GV)}

Germination value was recorded is an index combining speed and completeness of seed germination. It was calculated as per the method given by Czabator (1962):
$\mathrm{GV}=\mathrm{PV} \times \mathrm{MDG}$

Where, GV = Germination value

$\mathrm{PV}=$ Peak value of germination and

$\mathrm{MDG}=$ Mean daily germination

\section{Mean germination time (MGT)}

Mean germination time was recorded the time taken to complete germination was determine as MGT in days according to Bonner (1983) and Dey (2012) as given in below:

Mean Germination Time $=$

$$
\Sigma \text { (Daily germination x Days) }
$$

Number of seed sown

Where, $\mathrm{n}=$ number of seed, which was germinated on day $\mathrm{D}$, and $\mathrm{D}$ is number of days counted from the beginning of germination

\section{Seedling vigor index (SVI)}

The seedlings vigour index was calculated as per the formula given by Abdul-Baki and Anderson, 1973. It reflexes the health of the seedling produced.

SVI $=$ Germination percentage $(\%)$ x Seedling length $(\mathrm{cm})$

\section{Drupe (Seed with pulp) weight}

Hundred droupe weight of three replicates (each of 100 randomly selected capsules) for each source was recorded up to two decimal points as per ISTA (1996) rules using an electrical pan balance.

\section{Seed moisture content (\%)}

It was determined as per ISTA rule, 1999. Three randomly drawn samples of seed in 
each seed sources were measured for fresh weight by placing each sample in the metal container. Then the metal container was placed in a hot air oven at $60^{\circ} \mathrm{C}$ for 7 days and re-weight until a constant weight had reached with the help of electronic balance. The moisture content was calculated as per the following formula:

Moisture content $(\%)=$

Fresh seed weight - Dry seed weight X 100 Fresh seed weight

\section{Results and Discussion}

Drupe (seed) data were recorded of ten seed sources which are Seed germination on daily basis have been furnished in Figure 1, germination value in figure 2, Mean germination time (days) in figure 3 , seedling vigor index in figure 4 , seed weight in figure 5 , and moisture content of seed figure 6 respectively, before sowing seed two different treatment were performed (i.e. pre-treated water and control).

\section{Seed germination percentage}

Pre-treated water Seed sources of Naryanpura gave maximum germination percentage (94.33\%), which was followed by Bilaspur (93.35\%) and Bametera (90.55\%) (Fig 1) while minimum value of germination percentage was recorded from Dhamatari $(85.89 \%)$. Where in the control there was no treatment recorded germination percentage Bilaspur ( $91.00 \%)$, followed by balod ( 88.63 $\%$ ) while the minimum value of germination percentage was recorded from Dhamatari $(83.00 \%)$. The differences for seed parameters was recorded significant $(\mathrm{p}=0.05)$ among all seed sources. The same trend of significant was also observed in the year of study and seed sources. The present observations of this study are close agreement with the findings of
Pandey et al., (2002), Naidu et al., (2001) in Sapindustr foliatus; and Kumar et al., (2003) in Gmelina arborea. Milberg et al., (1996) opined about the larger variability in germination parameters if seed lots are in wider variation. Seeds of a single species differ in germination when seeds are collected from different places and this phenomenon may be associated with altitude (Holm, 1994; Vera, 1997).

\section{Germination value (GV)}

In Fig. 2 seed sources of Bilaspurgave maximum germination value (6.05) which was followed by Balod (5.96) and Kondagaon (5.87) while minimum germination value was recorded from Demetara (4.00), were in the control there was no treatment recorded highest germination value Bilaspur (5.02), followed by balod (5.76)while minimum value of germination value was recorded from Bemetera (4.60). The differences for seed parameters was observed significant $(\mathrm{p}=0.05)$ among all seed sources. The same trend of significant was also observed in the year of study and seed sources. Germination value is a further expression of germination energy and has been used as an integrated measure of seed quality in Pinus roxburghii (Roy et al., 2004), Acacia nilotica (Ginwal and Gera, 2000); Besides germination percentage, the variation in germination value among different pretreatments in the different seed sources are well in conformity with the findings of Hossain (2001) in Tectona grandis; in Albizzia lebbeck (Mutha et al., 2004).

\section{Mean germination time (MGT)}

In Fig. 3, seed sources of Pendra gave maximum Mean germination time (20.59) which was followed by Bemetera (20.40) and Gariband (20.22) while minimum germination value was recorded from Bijapur (19.44), 
Where in the control there was no treatment recorded highest Mean germination time Bemetera (21.24), followed by Kondagaon (21.23) and Mahasamuand (21.15) while minimum value of mean germination time was recorded from Naryanpur (20.34).The differences for seed parameters was significant $(\mathrm{p}=0.05)$ among all seed sources. The same trend of significant was also observed in the year of study and seed sources. This finding is justified the hypothesis that better germination will take lesser time (MGT) to germinate. This explanation could be on the basis that activities in seed embryo go faster resulting in the utilization of accumulated food material and early germination. Lepcha (2015) in Swietenia mahagony, Roy et al., (2004) reported somewhat similar results in seeds of Pinus roxburghii.

\section{Seedling vigor index (SVI)}

In Fig. 4, seed sources of Bilaspur gave maximum Seedling vigor index (SVI) (3744.27) while minimum Seedling vigor index (SVI)was recorded from Bijapur (2885.74) which was followed by Pendra (2989.40), Where in the control there was no treatment recorded highest Seedling vigor index (SVI) Bilaspur (3854.76), while minimum Seedling vigor index (SVI) was recorded from Pendra (2979.07) which was followed by Gariaband (2985.46). The differences for seed parameters was noticed significant $(p=0.05)$ among all seed sources. The same trend of significant was also observed in the year of study and seed sources.

Table.1 Geographic characteristics of seed sources of Azadirachta indica

\begin{tabular}{|c|c|c|c|c|c|}
\hline $\begin{array}{c}\text { S. } \\
\text { No. }\end{array}$ & $\begin{array}{c}\text { Name of seed } \\
\text { Source }\end{array}$ & District/ State & $\begin{array}{c}\text { Latitude } \\
(\mathbf{N})\end{array}$ & $\begin{array}{c}\text { Longitude } \\
(\mathbf{E})\end{array}$ & $\begin{array}{c}\text { Altitude } \\
(\mathbf{m s l})\end{array}$ \\
\hline $\mathbf{1 .}$ & Balod & Balod, Chhattisgarh & $20.73^{\circ}$ & $81.2^{\circ}$ & 326 \\
\hline $\mathbf{2 .}$ & Bilaspur & Bilaspur, Chhattisgarh & $22.09^{\circ}$ & $82.15^{\circ}$ & 208 \\
\hline $\mathbf{3 .}$ & Bemetara & Bemetara, Chhattisgarh & $21.70^{\circ}$ & $81.53^{\circ}$ & 282 \\
\hline $\mathbf{4 .}$ & Bijapur & Bijapur, Chhattisgarh & $18^{\circ} 47^{\prime} 30^{\prime \prime}$ & $80^{\circ} 49^{\prime} 0^{\prime \prime}$ & 303 \\
\hline $\mathbf{5 .}$ & Dhamtari & Dhamtari, Chhattisgarh & $20.71^{\circ}$ & $81.55^{\circ}$ & 319 \\
\hline $\mathbf{6 .}$ & Gariaband & Gariaband, Chhattisgarh & $20^{\circ} 38^{\prime} 0^{\prime \prime}$ & $82^{\circ} 4^{\prime} 0^{\prime \prime}$ & 340 \\
\hline $\mathbf{7 .}$ & Pendra & Pendra Chhattisgarh & $22.77^{\circ}$ & $81.95^{\circ}$ & 593 \\
\hline $\mathbf{8 .}$ & Kondagaon & Kondagaon, Chhattisgarh & $19.6^{\circ} \mathrm{N}$ & $81.67^{\circ}$ & 596 \\
\hline $\mathbf{9 .}$ & Mahasamund & Mahasamund, Chhattisgarh & $21.11^{\circ}$ & $82.10^{\circ}$ & 321 \\
\hline $\mathbf{1 0 .}$ & Narayanpur & Narayanpur, Chhattisgarh & $19.7167^{\circ}$ & $81.2500^{\circ}$ & 540 \\
\hline
\end{tabular}


Fig.1 Germination percentage of Azadirachta indica

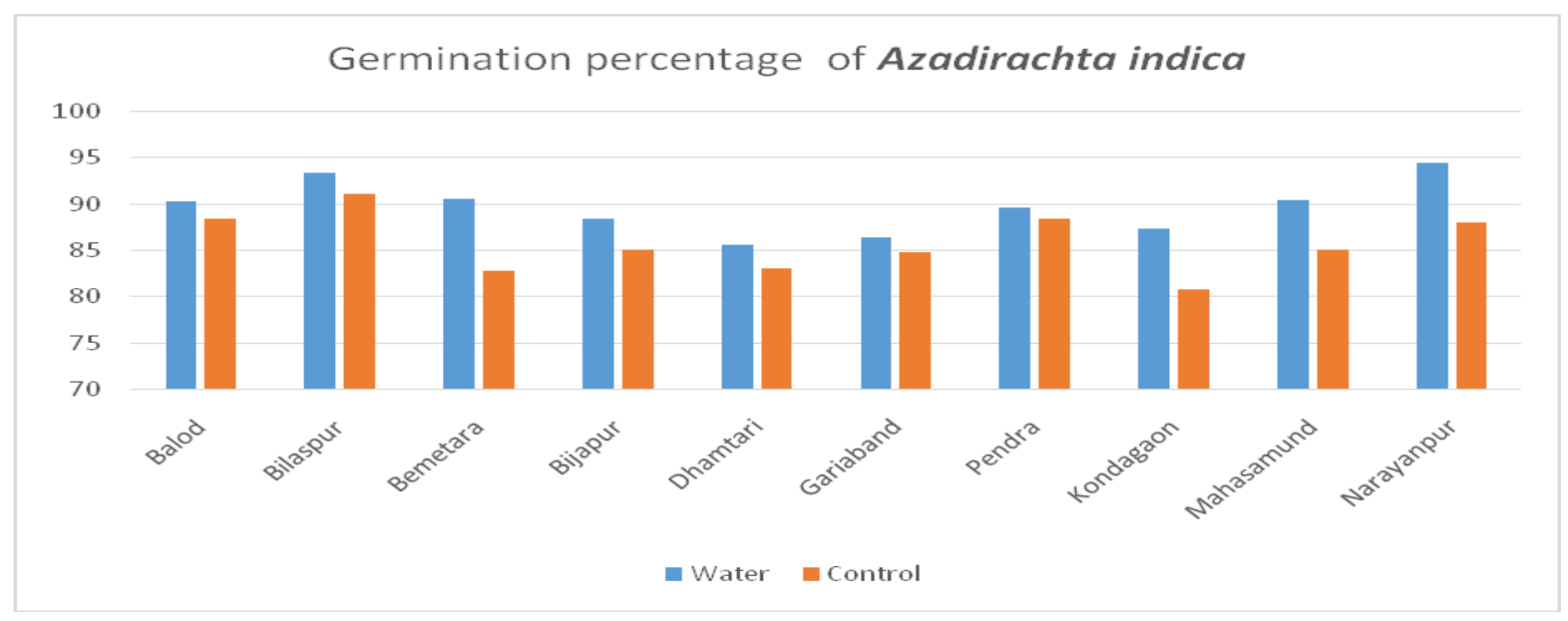

Fig.2 Germination Value of Azadirachta indica

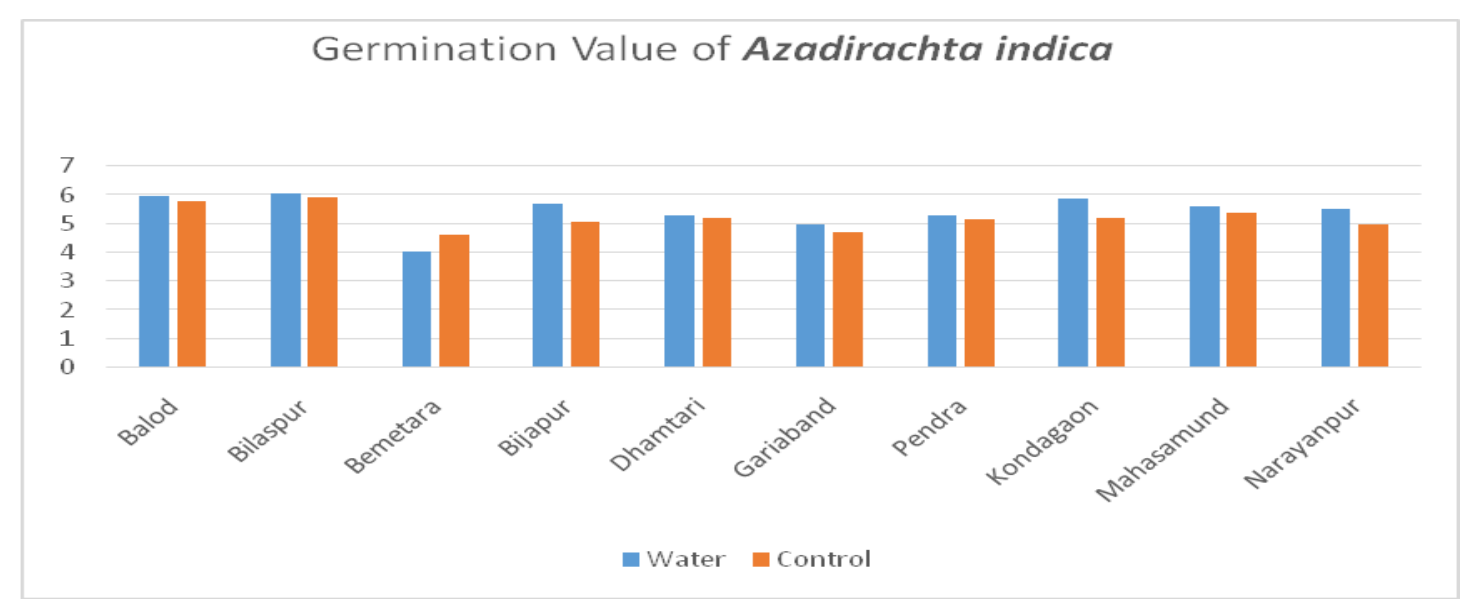

Fig.3 Mean germination time (Days) of Azadirachta indica

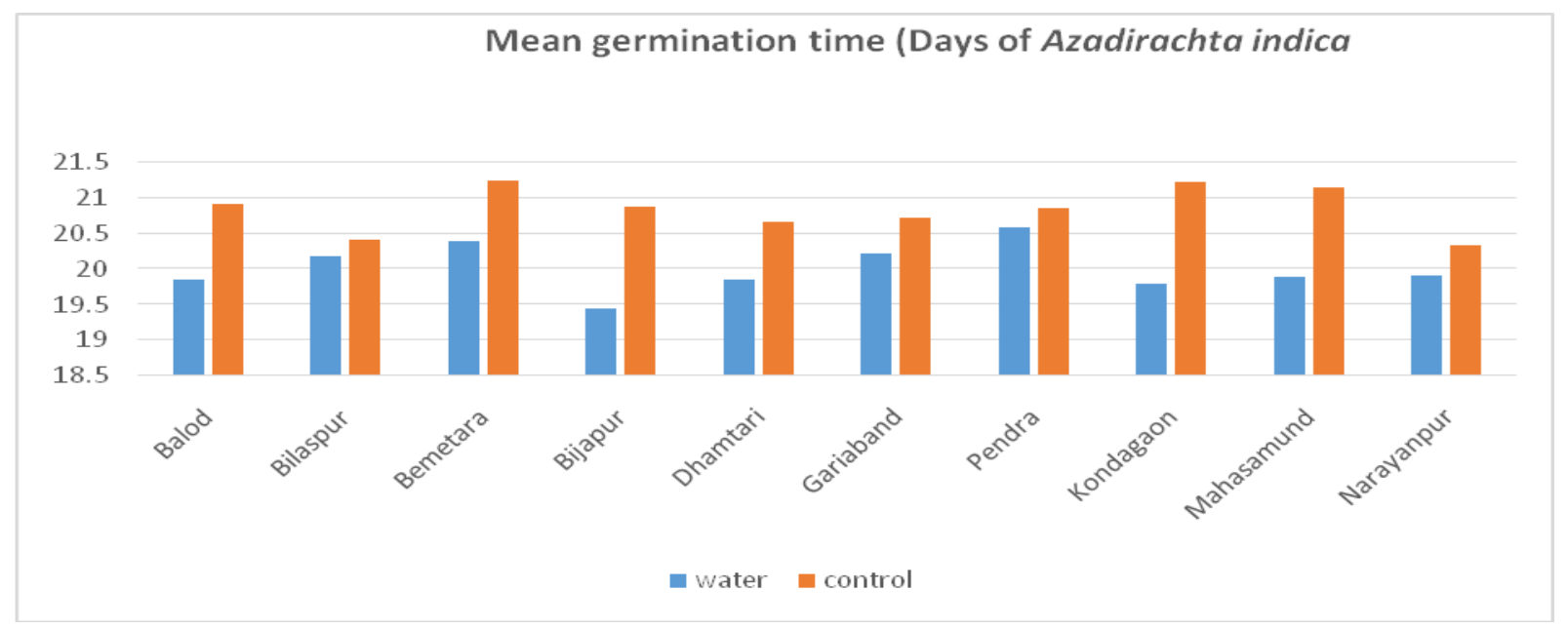


Fig.4 Seedlings vigour Index of Azadirachta indica

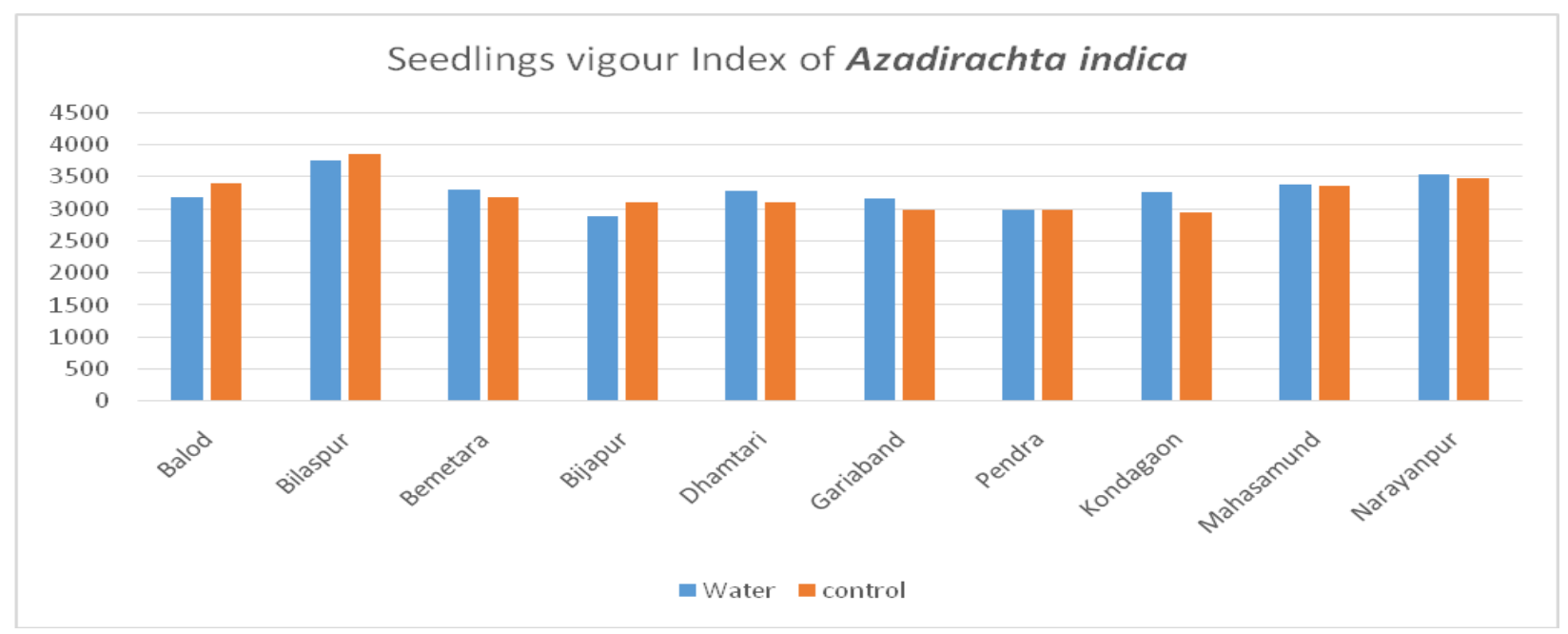

Fig.5 100 seed weight (g) with pulp

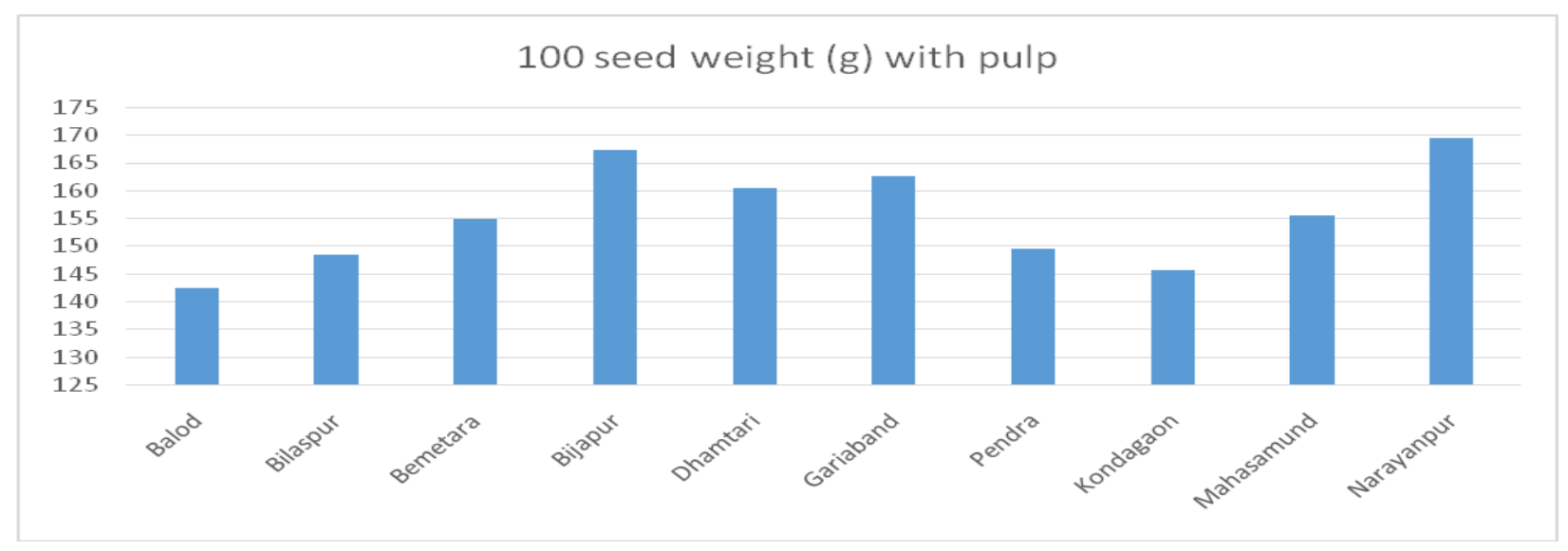

Fig.6 100 seed weight (g) without pulp

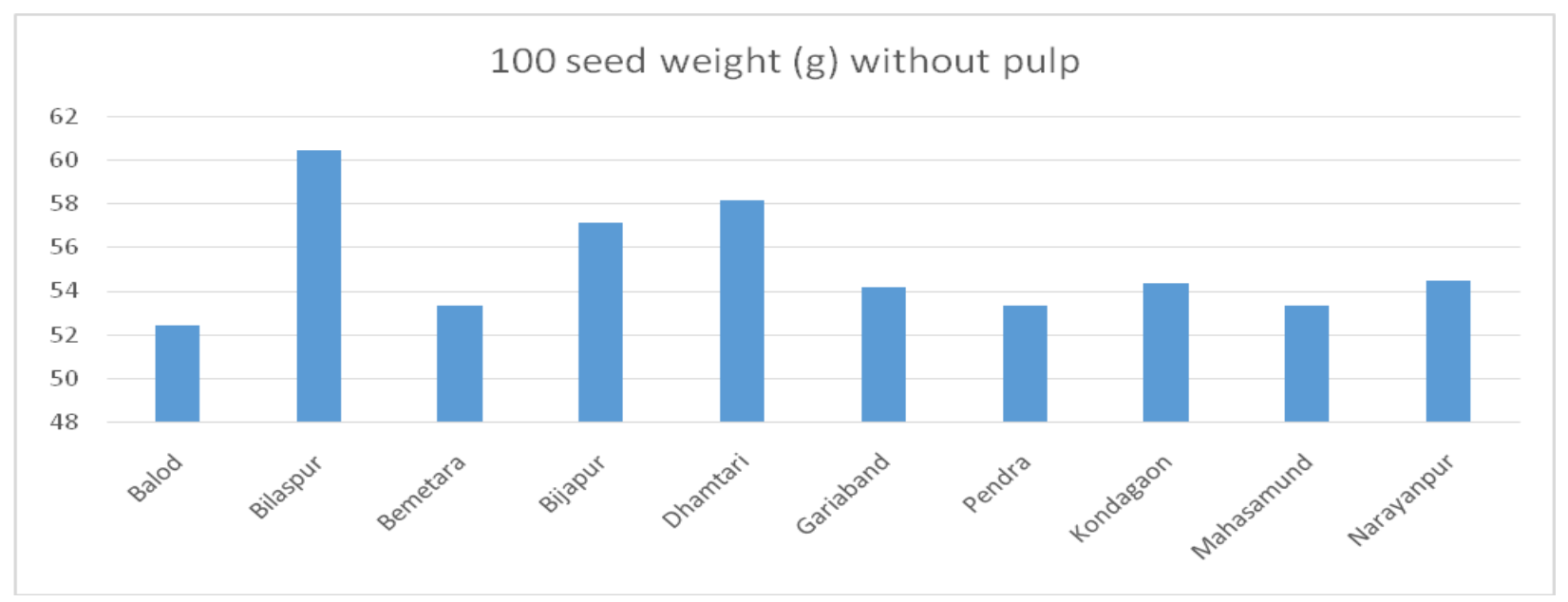


Fig.7 Moisture content of seed (\%)

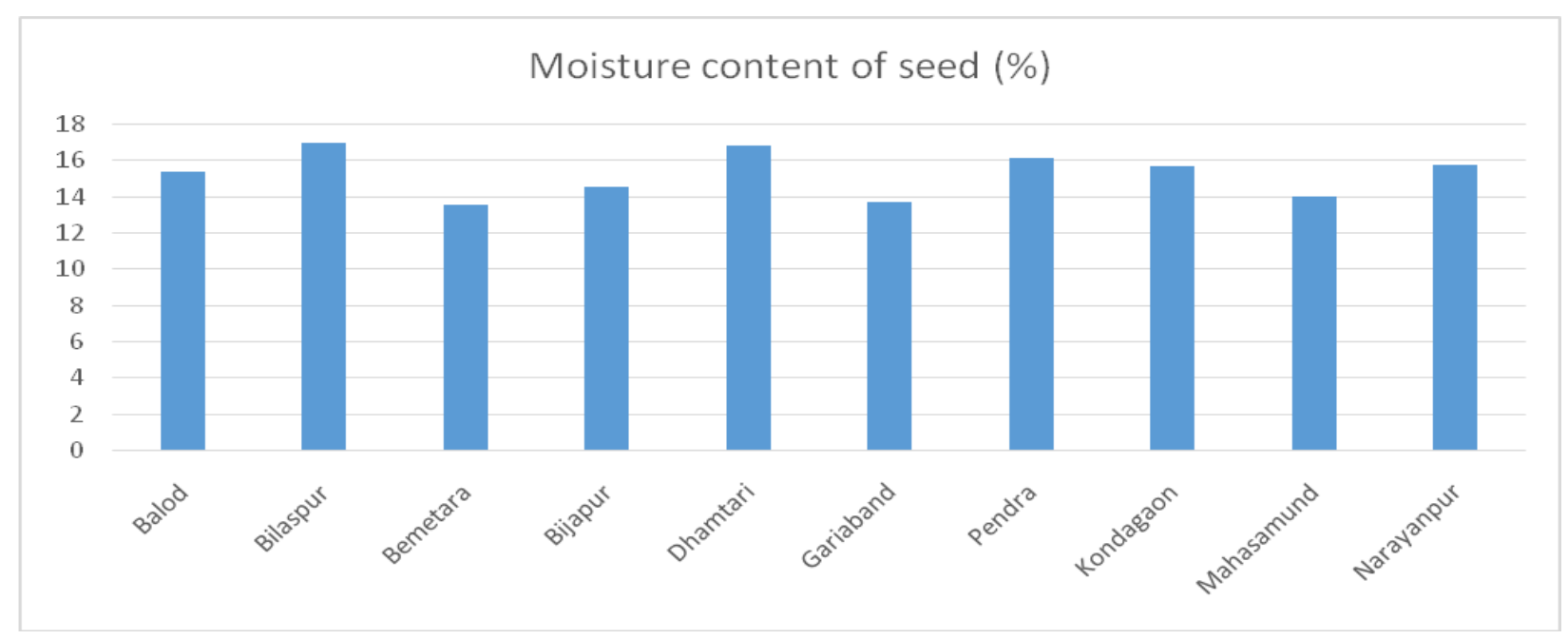

\section{Drupe (Seed) weight (g) with pulp}

In Fig. 5, seed sources of Bilaspur gave maximum Drupe weight (169.36g), which was followed by Dhamtari (167.38g), where lowest Drupe weight was recorded Balod $(142.34 \mathrm{~g})$. The differences for seed parameters were significant $(\mathrm{p}=0.05)$ among all seed sources. This might be due to different environment at different geographic regions of each seed source and seasonal variables (Murali, 1997) (Table 1). Result of adaption to diverse environmental conditions throughout their range of distribution (Mathur et al., 1984). Besides the age, vigour, crown structure and genotype of the mother plant, the locality factors of seed origin are important factors affecting seed traits (Salazar and Quesada, 1987). Such variations about the habitat have also been reported by Gera $e t$ al., (2000) in Dalbergia sissoo Wang et al., (1998) in Pinus bungeana (1998).

\section{Drupe (Seed) weight (g) without pulp}

In Fig. 6, Seed sources of Bilaspur gave maximum Drupe weight without pulp (60.46g), which was followed by Dhamtari $(58.15 \mathrm{~g})$, where lowest Drupe weight without pulp was recorded Balod (52.41g). The differences for seed parameters were significant $(p=0.05)$ among all seed sources. The same trend of significant was also observed in the year of study and seed sources.

\section{The moisture content of seed (\%)}

In Fig. 7, seed sources of Bilaspur gave maximum Moisture content (16.91\%), which was closely followed by Dhamtari $(16.81 \%)$ and Pendra (16.12\%), where lowest Moisture content was recorded Bemetera (13.51\%) which was closely followed by Gariaband $(13.71 \%)$. The differences for seed parameters was recorded significant $(\mathrm{p}=0.05)$ among all seed sources. This finding is a good agreement with the findings of Roberts (1973) who highlighted the variation in the moisture content of seed and altitude of seed source may be attributed to the environmental effects before, during and immediately after harvesting of seeds.

\section{Acknowledgement}

First of all, with limitless modesty, I would like to bow before Parents and Lord Krishna, the almighty for blessing me with enough patience and strength to go through 
challenges of life. Deep regards and eternal gratitude to all my family and all teachers whose selfless sacrifices, blessing and inspirations have made my achievements possible. I would like to thank my parents and friends who helped me a lot in finalizing this research work. I am fully responsible for any shortcoming that remains.

\section{References}

Abdul-Baki, A. A. and Anderson, J. D. 1973. Vigor determination in soybean seed by multiple criteria 1. Crop science, 13(6), 630-633.9.

AOSA. 1976. Progress report on seed vigour testing handbook, Assoc. off. Seed Anal. News Letter, 50(2), pp78.

Bewley, J. D., \& Black, M. (1978). The structure of seeds and their food reserves. In Physiology and Biochemistry of seeds in relation to germination (pp. 7-39). Springer, Berlin, Heidelberg.

Bonner, F.T. 1983. Germination responses of loblolly pine to temperature differentials on a two-way thermo-gradient plate. Journal of Seed Technology, 8(1):6-14.

Czabator, F. J. 1962. Germination value: an index combining speed and completeness of pine seed germination. Forest science, 8(4), 386-396.

Dey, R., Hoffman, P. S., and Glomski, I. J. 2012. Germination and amplification of anthrax spores by soil dwelling amoeba. Applied and Environmental Microbiology, AEM-02034.

FAO. 1985. A Guide to Forest Seed Handling: with special reference to tropics. FAO forestry paper No. 20/2. FAO, Rome, pp. 379.

Gera, M., Gera, N.andPurohit, M. 2000. Source variation in seed and germination characteristics in Acacia nilotica willd. Ex.Del. Seed Research, 28 (1): 27-31
Ginwal, H. S. and Gera, M. 2000. Genetic variation in seed germination and growth performance of 12 Acacia nilotica provenances in India. $J$. Tropical Forest Science, 12(2):286-297

Holm, S. O. 1994. Reproductive patterns of Betula pendula and B. pubescens coil. along a regional altitudinal gradient in Northern Sweden. Ecography, 17: 6072.

Hossain, M. A., Arefin, M. K., Khan, B. M., \& Rahman, M. A. 2001. Effects of seed treatments on germination and seedling growth attributes of Terminalia chebula in the nursery. Research Journal of Agriculture and Biological Sciences, 1(2), 135-141.

ISTA (International Seed Testing Association), 1999. International rules for seed testing. Rules 1999 (No. Suppl).

ISTA (International Seed Testing Association),1996. International rules for seed testing. Rules and annexes. Seed Science \& Technology, 24: 3177.3.

Kumar, A; Singh, A. N., Kalita, R. K. and Prasad, K. G. 2003. Gmelina arboreaA Technology Mission. RFRI, Jorhat, Assam, India.

Lepcha, U. 2015. Standardization of nursery practices for production of quality planting stocks of Mahogany (Swietenia mahagoni (Linn.) Thesis Master of Science, UBKV. West Bengal.

Mathur. R. S., Sharma, K. K. and Rawat, S. 1984. Germination behavior of various provenance of Acacia nilotica sub species India. Indian Forester, 110:435449.

Milberg, P., Andersson, L., Elfuerson, Regner, S. 1996. Germination characteristics of seeds differing in mass. Seed Science Research, 6: 191197.

Murali, K. S. 1997. Patterns of seed size, 
germination and seed viability of tropical tree species in Southern India. Biotropica, 29(3): 271-279.

Mutha, N., Bohra, M. D., Burman, U. and Harsh, L. N. 2004. Effect of seed size and pretreatments on germination of Albizia lebbeck (L.) Benth. Indian Journal of Forestry, 27 (1): 11-14.

Naidu, C. V., Prasada Reddy, B. V. and Rao, P. S. 2001. Effect of nitrogenous salts on germination of Soapnutsapindus trifoliatusvahil. Indian Journal of Forestry 24(1): 90-92.

Pandey, S., Jamaluddin; Bisht, S. and Pant, N.C. 2002. Germination behavior of Gmelina arborea Roxb. influenced by stone size. Seed Research, 30(2): 279283.

Roberts, E. H. 1973. Predicting the storage life of seeds. Seed Science and Technology, 1: 499-514.

Roy, M., Thapliyal, R. C. and Phartyal, S. S. 2004. Seed source variation in cone, seed and seedling characteristics across the natural distribution of Himalayan low level Pine Pinurox burghii Sarg. Silvae Genetica, 53(3):116-123.

Salazar, R and Quesada, M. 1987. Provenance variation in Guazuma umifolia L. in Costa Rica. Commonwealth Forestry Review, 66(4): 317-324.

Vera, M.L. 1997. Effects of altitude and seed size on germination and seedling survival of heatland plants in North Spain. Plant Ecology, 133:101-106.

Vlase, I. and Voinesou, L. 1972. Intensity of fruiting and quality of the harvested seeds in Piceaabies. Revista Padurilur, 87(8): 355-356.

Wang, X., Liu, J., Wang, Jiulin; Liu, C., Wang, X.P., Liu, J.L., Wang, J.L. and Liu, C.J. 1998. Geographical variation of the morphological characteristics of Pinus bungeana seeds and cones. Journal of Beijing Forestry. 20 (3): 2531.

\section{How to cite this article:}

Sharda Dubey and Gaurav Kumar Padwar. 2020. Studies on Germination Behaviour of Respective Seed Sources of Azadirachta indica. Int.J.Curr.Microbiol.App.Sci. 9(08): 27182727. doi: https://doi.org/10.20546/ijcmas.2020.908.308 